\title{
The Concept of Social Marketing while Supplying the Population with Liquefied Gas
}

\author{
L.K. Kirillova ${ }^{1, *}$, G.A. Korzhova ${ }^{1}$, L.H. Mukhametzyanova ${ }^{1}$ and A.V. Banartseva ${ }^{2}$ \\ *Corresponding author: kirillova-09@mail.ru \\ ${ }^{1}$ Samara State Economic University, Samara, Russia \\ ${ }^{2}$ Samara State Technical University, Samara, Russia
}

\begin{abstract}
The article analyzes the specificity of the marketing activities of the gas supplying organization involved in the socially significant projects. Social marketing acts as a concept acceptable in conditions of increased corporate social responsibility of the society and organization. Consideration for the interests of a commercial organization requires support from government agencies in terms of subsidizing costs when supplying localities with liquefied gas, in the absence of pipelines and the economic viability of their construction. The most important condition providing the access of the population to natural gas is the choice of a reliable gas supplier that could compensate for lost income at the expense of other activities, and guarantee high quality public services. Assessment of the quality of customer service is an indicator of the effectiveness of the tasks set by the gas supplying organization and the criterion for selecting a partner organization for a social project of the public authorities. The paper assessed the competitive advantages of a gas supplying organization operating on the principles of social marketing. Recommendations are given on the development of the organization's activities while reducing the demand for liquefied gas supplies in the region.
\end{abstract}

Keywords: marketing, social marketing, socially responsible marketing, customer satisfaction.

\section{Introduction}

Marketing activity in this regard is of an applied nature and the types of decisions taken depend on the scope of the marketing theory and its tools. The development of market institutions and a profit orientation remain the cornerstone of business growth and business continuity. At the same time, the state assumes the responsibility for social equality and ensuring equal population's access to the resources. The vast territory of the Russian Federation requires significant resources for the formation of the gas transmission system. However, the wide geography of rural settlements with a small population brought the validity of economic effect from the operation of such infrastructure facilities into question.

This raises the problem of justifying the option of providing the population of small rural settlements with natural gas, and developing solutions to create customer satisfaction and compliance with existing legislation in the field of gas supply regulation. "The current stage of development of marketing activities is characterized by an increasing trend towards marketing relationships (loyalty), according to which the main efforts of an enterprise should be aimed at not only short-term result of a single transaction, but at establishing relationships with the consumer that are mutually beneficial in the long term [1, p. 56]. The participation of the gas supplying company in the implementation of sociallyoriented projects works towards creation of lasting competitive advantages and improvement of the company image in the eyes of the population.

\section{Problem Statement}

The concept of social marketing was first formulated by Professor F. Kotler in 1971. The content of this marketing direction is the solution of social problems, implementation of social ideas and social actions [2]. Currently, enterprises developed a course of action related to solving social problems and maintaining the image of a socially responsible company that participates in solving social problems.

It should be recognized that the concept of social responsibility is a broader concept and is implemented not only in the sale of goods and services, promotion of a positive image of the company, but also includes the organization's responsibility for the consequences of its activities, predetermines the search for solutions aimed at achieving social justice. Commercial organizations in a competitive environment seek to increase customer interest in their organization sending positive signs through participation in solving social problems of society. "Creating a positive image of the company implies its constant maintenance and confirmation by action" [3, p. 46].

Socially responsible marketing can be implemented in two directions - first, through drawing attention to the solution of a social problem and secondly, through participation in solving a social problem and focusing on the consequences of this decision. In carrying out these activities, companies do not set a goal of making a profit, but create a positive image and can receive subsidies from the state to cover costs. 


\section{Research Questions}

"Economical development takes place in constantly changing market environment, which has an impact on the nature and specificities of business processes and phenomena" [4, p.1093]. In the current context, the issues of providing the population with liquefied natural gas, especially in remote settlements, where there is no infrastructure for transportation of natural gas, have acquired particular relevance. This activity is regulated and the right to conduct this business is granted only to organizations that meet a number of requirements: the availability of gas filling stations and points; the possibility of inspection and maintenance of gas cylinders; availability of gas cylinders storage; availability of repair departments for gas equipment; provision of emergency repair at the place of residence or location of the customers; transportation of liquefied gas by specialized transport;

All these requirements are met in the Samara market by LLC Srednevolzhskaya Gas Transmission Company (LLC SVGC), which annually confirms the status of an authorized gas distribution organization on the basis of a license. This type of activity is related to socially significant projects and provides for the gas supply to the territories of the Samara Region, including remote areas that are supplied exclusively with liquefied gas. On the orders of the Ministry of Energy and Public Utilities of the Samara Region, participation in this project involves the delivery of liquefied gas at social prices subsidized by the budget of the Samara Region. In this regard, profit-making is not an end in itself, the project sets out several other crucial objectives. They address issues of customer satisfaction and quality assessment of the core functions in the context of the project. The characteristics of management approaches in this situation require an assessment of the economy of the gas supply market and key success factors in this market. Based on the open data on the company's activities, we will analyze its strengths and weaknesses and the factors that need to be considered for successful operation in the market [5].

The largest is the branch "Samaragaz", which unites 15 rural departments and 6 management services of gas facilities to serve consumers in Samara. At the same time, in the Samara region there are rural settlements that do not have access to the gas transmission system, but have a need for gas supply. These are the issues that need to be addressed, technologically and economically, and that are implemented in practice through the provision of consumers with liquefied gas. Liquefied natural gas supply is part of the activities of the company LLC Samaragaz, along with the maintenance of gas facilities, design and survey work and installation. The study of the success factors of a company requires a study of the macro environment, promoting realization of the competitive advantages of the organization. Based on open sources, a PEST analysis of the Middle Volga gas company has been carried out. The data presented in Table 1 show the significant role of political factors in the development of the industry.

Table 1. PEST analysis of the Middle Volga gas company

\begin{tabular}{|c|c|c|c|c|c|}
\hline Activity & Main factors & Characterization & Probability & Impact & Response \\
\hline Policy & $\begin{array}{l}\text { 1. Regulation } \\
\text { of the industry } \\
\text { by public } \\
\text { authorities; } \\
\text { 2. Legislative } \\
\text { changes in the } \\
\text { functioning of } \\
\text { organizations; }\end{array}$ & $\begin{array}{l}\text { The regulatory } \\
\text { function of the } \\
\text { state is to develop } \\
\text { gasification } \\
\text { programs and } \\
\text { ensure energy } \\
\text { security. } \\
\text { Special attention } \\
\text { should be paid to } \\
\text { the study of } \\
\text { legislation in the } \\
\text { field of tariffs for } \\
\text { gas and heat } \\
\text { supply; }\end{array}$ & $\begin{array}{l}\text { High } \\
\text { (1-2 years) }\end{array}$ & $\begin{array}{l}\text { New } \\
\text { requirement } \\
\text { s for energy } \\
\text { security } \\
\text { programs. } \\
\text { Legislative } \\
\text { regulation } \\
\text { of these } \\
\text { issues }\end{array}$ & $\begin{array}{l}\text { Changes in the } \\
\text { financial strategy } \\
\text { of an enterprise } \\
\text { with the } \\
\text { changing rules } \\
\text { and regulations } \\
\text { of the industry. } \\
\text { Changes in tariff } \\
\text { plans for } \\
\text { responding new } \\
\text { legal } \\
\text { requirements to } \\
\text { ensure } \\
\text { profitability of } \\
\text { business. }\end{array}$ \\
\hline Economy & $\begin{array}{l}\text { 1. } \\
\text { Hydrocarbon } \\
\text { consumption } \\
\text { growth } \\
\text { 2. Investment } \\
\text { attractiveness }\end{array}$ & $\begin{array}{l}\text { Industrial } \\
\text { recovery and } \\
\text { increasing } \\
\text { demand for gas as } \\
\text { an essential } \\
\text { source. Growing } \\
\text { demand for gas } \\
\text { contributes to } \\
\text { increasing the } \\
\text { investment } \\
\text { attractiveness of } \\
\text { the industry. }\end{array}$ & $\begin{array}{l}\text { Average } \\
\text { (5 years) }\end{array}$ & $\begin{array}{l}\text { Increasing } \\
\text { gas demand, } \\
\text { increasing } \\
\text { investment } \\
\text { attractivenes } \\
\mathrm{s}\end{array}$ & $\begin{array}{l}\text { Increase in } \\
\text { business activity, } \\
\text { creation of } \\
\text { favorable climate } \\
\text { for investment } \\
\text { providing } \\
\text { additional } \\
\text { capital. }\end{array}$ \\
\hline
\end{tabular}




\begin{tabular}{|c|c|c|c|c|c|}
\hline Society & $\begin{array}{l}\text { Educational } \\
\text { level of the } \\
\text { population }\end{array}$ & $\begin{array}{l}\text { Possibility to } \\
\text { attract } \\
\text { experienced } \\
\text { highly skilled } \\
\text { staff }\end{array}$ & $\begin{array}{l}\text { Low } \\
\text { (5-10 years) }\end{array}$ & $\begin{array}{l}\text { New } \\
\text { educational } \\
\text { technologies } \\
\text { and } \\
\text { emergence } \\
\text { of personnel } \\
\text { with new } \\
\text { competencie } \\
\text { s. } \\
\end{array}$ & $\begin{array}{l}\text { Qualified staff } \\
\text { with high } \\
\text { knowledge } \\
\text { development } \\
\text { skills }\end{array}$ \\
\hline $\begin{array}{l}\text { Technolo } \\
\text { gy }\end{array}$ & $\begin{array}{l}\text { New gas } \\
\text { transportation } \\
\text { technologies }\end{array}$ & $\begin{array}{l}\text { Technological } \\
\text { upgrading of gas } \\
\text { transmission } \\
\text { process }\end{array}$ & $\begin{array}{l}\text { Average ( } 5 \\
\text { years) }\end{array}$ & $\begin{array}{l}\text { The } \\
\text { emergence } \\
\text { of new ways } \\
\text { of gas } \\
\text { transport }\end{array}$ & $\begin{array}{l}\text { Improving gas } \\
\text { transportation } \\
\text { efficiency }\end{array}$ \\
\hline
\end{tabular}

Source: compiled by the authors according to official data of LLC Srednevolzhskaya Gas Company.

Liquefied gas supply relates to maintaining normal gas supply in remote areas of the Samara Region distant from the regional center and gas transportation infrastructure facilities. Liquefied gas supply to remote areas is provided at social prices and is not profitable. Thus, the company is involved in social marketing, receiving subsidies to cover related costs from responsible authorities. Within the frame of this social project, LLC SVGC calculates the annual need for liquefied gas and organizes its supply. The analysis of these works indicates an increase in the cost of gas supply. The reasons for this increase in costs are the increase in the wholesale gas prices, inflation processes, insufficient subsidies, and the lack of provisions for losses of the previous years. In general, the results of the organization's work on the supply of liquefied gas to the population are presented in Table 2 .

Table 2. Dynamics of sales figures for liquefied gas LLC "SVGC",\%

\begin{tabular}{|l|l|l|l|l|}
\hline № & Indicators & 2015 & 2016 & 2017 \\
\hline 1 & Volume of gas sold & 100 & 88,1 & 84,2 \\
\hline 2 & Revenues from population & 100 & 95,2 & 96,5 \\
\hline 3 & Total costs & 100 & 90,9 & 100,8 \\
\hline 4 & Amount of losses & 100 & 89,28 & 102,5 \\
\hline 5 & Subsidies received & 100 & 100 & 100 \\
\hline 6 & Amount of uncovered losses & 100 & 71,04 & 106,8 \\
\hline
\end{tabular}

Source: compiled by the authors.

To preserve trade secrecy, calculations are carried out in relative terms. The figures show that by 2017 gas supply volumes were gradually decreasing, representing $16 \%$ compared to 2015 . At the same time, revenues from gas sales to the population decreased by $3.5 \%$, while costs for a smaller amount of work increased by $0.8 \%$. The amount of the subsidies provided was fixed and did not change for three years. In general, the amount of uncovered losses increased in 2017 by $6,8 \%$.

In this situation, the urgent question arises regarding the assessment of the prospects for liquefied gas demand. The most realistic way to increase sales could be access to neighboring regions, in particular in the Ulyanovsk, Orenburg and Saratov regions for serving private consumers.

The additional external environmental factor that should be taken into account in connection with the activities of LLC SVGC, is the new gasification program for the Samara Region, which includes the reconstruction of existing networks and the necessity of liquefied gas supply to consumers during the period. In general, the liquefied petroleum gas supply should be considered as a product for a specific market segment, and the expansion of sales is hampered by the development of gas transportation infrastructure.

\section{Purpose of the Study}

This study is aimed at finding ways to increase consumer satisfaction in gas supply services for the population using liquefied gas due to the lack of alternative methods. The social significance of this project is caused by the role of the State in ensuring the right of equal access to resources for all citizens and readiness to financially support all organizations capable of performing this work. The formation of customer service quality indicators is an important avenue to accomplishing that objective. The specifics of the organization's activities brought into focus the security of gas supply and the creation of conditions for the preservation of civilian property.

In order to organize the work of LLC SVGC on the principles of marketing, a number of estimated indicators/figures are required which are declared as binding by the Ministry of Energy of the Russian Federation dated December 15, 2014. Order No. 926 "On approval of the methodology for calculating projected and actual values of reliability and quality of gas transportation services through gas distribution networks (GDN)": the number of failures in gas transportation through gas distribution networks to consumers; the duration of failure in gas supply through gas distribution networks to consumers; the volume of gas that has not been received by consumers as a result of elimination or restriction of transportation through gas distribution networks (hereinafter referred to as the amount of 
undelivered gas).

The same document regulates the quality values of the product (gas) and the necessary binding requirements: the required gas pressure at the consumer's gas connection point that corresponds to the gas household appliances; physical and chemical characteristics of the gas at the connection point should meet the regulatory and technical requirements;

Compliance with these conditions is a prerequisite for participation in this field of activity and requires development of specific criteria for their monitoring. As a rule, in practice such requirements are expressed in the form of ongoing monitoring and the analysis of deflection from the stated parameters is an indicator of management decision-making.

\section{Research Methods}

The work is based on the information analysis of the activities of LLC "SVGC" available in open sources. To assess the state of economic indicators we used methods of comparison, calculation of growth rates, and correlation and regression studies of dependencies of the volume of liquefied gas sold on the number of consumers living in the service area.

\section{Findings}

Social marketing is aimed at ensuring socially important functions, it is regulated by legislative norms and requires the participants to strictly fulfill the specified quality criteria for the tasks performed. Discussion focused on ensuring quality parameters of customer service, rather than making a profit. Compensation of expenses from such activities is carried out by the authorities in order to fulfill social obligations to the population. The goal of the public authorities is to choose an organization capable of fulfilling its intended purpose.

\section{Conclusion}

Development of market environment creates a competitive environment with competition for increased demand for goods and services. Competition in a broad sense affects all participants interested in exchange processes. Part of the needs cannot be met only on the basis of trade-market relations, but requires compliance with the principle of social equality of citizens, full access to life-support resources, such as gas supply, energy consumption, and water supply. Implementation of the rights of citizens to access such resources requires the participation of the state providing incentives for commercial organizations to implement unprofitable projects. At the same time, the compensation of the expenses of a commercial organization is accompanied by the maintenance of the image of a socially responsible company. This image becomes an additional competitive advantage for the commercial organization responsible for socially significant projects. Thus, development of the modern society suggests that the focus should be placed not only on profit-making, but also on social well-being of citizens, the guarantor of which is the State.

\section{References}

1. O.V. Yudakova, Planning marketing tools to manage customer loyalty. Bulletin of the Samara State University of Economics, 11(133), 56-60 (2015). [in Rus.].

2. F. Kotler, Fundamentals of marketing. Tutorial. Short course. Moscow: FILIN (1998).

3. L.A. Sosunova, G.A. Korzhova, V.V. Agafonova, V.M. Konev, E.P. Fomin, Features of the formation of the service sector in a market economy. Economic Sciences, 12(157), 44-47 (2017). [in Rus.].

4. L.K. Kirillova, Marketing aspects of import substitution in the market of cable and wire products. Economy and Entrepreneurship, 8(97), 1093-1096 (2018). [in Rus.].

5. Official page on the Internet of LLC "UGSC" [Electronic resource]. URL: http: // svgk.ru. Accessed: 12 November 2018. [in Rus.]. 